\title{
What are the current challenges facing Central Europe?
}

\author{
Andrew Barton and Jan Vávra \\ Envigogika 2013/VIII/2- Informace/ Information \\ Publikováno/Published 06 09. 2013 \\ DOI: http://dx.doi.org/10.14712/18023061.375
}

This was the theme of the third annual international interdisciplinary conference Our Common Present which took place at Charles University's Faculty of Arts on 24 April 2013 in cooperation between the University of South Bohemia's Economics Faculty, the Charles University Environment Center, and the University of Hradec Králové's Education Faculty.

Speakers who participated in the conference included representatives from most Central European countries, such as the German sustainability and agricultural consultant Karlheinz Knickel, the Hungary lawyer and economist from the University of Gödöllö, Tibor László Csegődi, and the Czech-Dutch university educationalist Peter Morée. Nor were representatives of organising institutions missing from the programme, which also included the economist Eva Cudlínová from the University of South Bohemia, and Jana Dlouhá from the Charles University Environment Center.

Unlike previous years, there was a perceptible move away from environmental themes only to wider societal issues. Individual contributions focused on the effectiveness of energy consumption in Hungarian towns (Tibor László Csegődi), changes in European agriculture and rural areas (Karlheinz Knickel), education for sustainable development in Central Europe (Jana Dlouhá and Andrew Barton), the specifics of Central European scientific projects (Bernhard Schneider), the economic strategy of the "Green New Deal" (Eva Cudlínová), creation of a local currency in the Hungary town of Šopron (Katarína Kohányiová), and the contemporary image of the church among of the Czech population (Peter Morée). The conference presentations were followed up by a concluding conference panel discussion in which the participants, including students, debated the current issues facing Central Europe.

Miloslav Lapka led the search for a common theme by reading out a contribution from Mikuláš Huba, a geographer and active Slovak politician. Contemporary challenges facing Central Europe are a part and parcel of global challenges, and this region faces a challenge over its own identity. Are existing institutions (the "Visegrad Four") connected to Central European history? Is the Central European region comprised of a sufficient autonomous network of relationships, cooperation and cultures? Is there a common strategy - game rules - for Central Europe? On the basis of the following discussion, we would have to say 'no'.

The following appeared to be key themes: modern education in Central Europe, real contemporary interdisciplinary issues and a sector approach to institutions, and a loss of confidence in traditional institutions, including primarily their representatives. These themes were strongly connected. Current Central European challenges can be summarised under 
the broad theme of sustainability: not only in the traditional sense of sustainable development, but also sustainability of the continuity of development, sustainability of the current state of education, and the prevailing mono-disciplinarity at the academic and institutional level.

In terms of education, Jana Dlouhá and Andrew Barton in particular looked at the impact education for sustainable development (ESD) is having in Central Europe, or rather the lack of much impact among the former socialist states of Central Europe: Czech Republic, Slovakia, Slovenia, Hungary and Poland. Whereas Germany and Austria enjoy relatively sophisticated networks geared toward embedding the concept of sustainable development within society at large through university curricula, green university campuses, and tertiary research goals, the same cannot be said of the newer democracies in the region, and the thought of sustainability informing higher education policy and curricula in those countries remains a distant goal. While lip service is paid to the formulation of national SD strategies in post-socialist states, and some may even boast ESD strategies, higher education administrators and policy makers for the most part remain wedded to the rigid university structures of the past where the notion of interdisciplinary cooperation, let alone cooperation with the non-academic sector, is a largely alien concept. Using spending on tertiary education research and per tertiary student as a percentage of GDP as very blunt proxies, one can see that the post-socialist Central European states are less well equipped than their western neighbours to meet the rapidly changing needs in higher education to prepare graduates for the social, economic, and environmental challenges of the future.

Another closely associated conference theme was the "rethinking" of Central Europe and the question of whether this region is capable at all of societal and social transformation, including rethinking communication. As can be seen from this short account, the relationship of the themes has its own internal logic. What can be appreciated is the on-going awareness of the importance to act (especially the eastern part of Central Europe, including Austria) as a distinctive, common region. This rethinking affects the environmental sciences as well as economics and sociology. What can they offer Central Europe?

An interesting role could be played by a modern design of cultural and social ecology in the sense of a cultural change as the result of changes to the environment - in this sense Central Europe has not come to terms with the challenge of heritage of rural areas, just like the challenge of its industrial heritage, including modernistic way of thinking and facing the challenge of energy consumption and its economics, and the social impact associated with it, and of course the environmental impacts.

Real interdisciplinary support, a renewal of trust in institutions and corresponding education is certainly not a specific challenge for the Central European region only. It is, however, a specific test of its identity.

For more on the conference, see http://www.ecoology.org . 


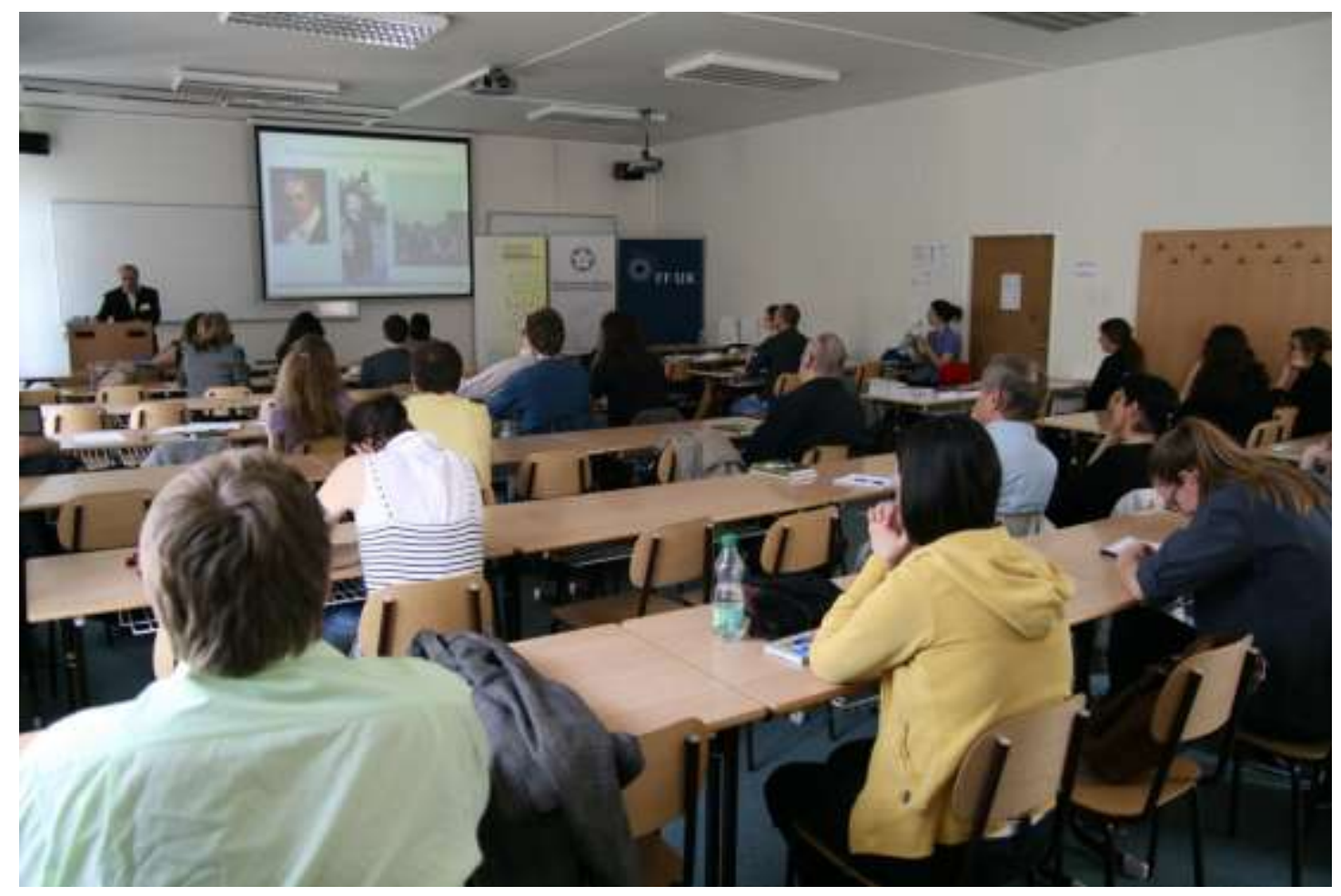

